\title{
Extended Ground for U.S.-China Competition?
}

\author{
Comparing China's and the U.S.' \\ Engagement with Africa
}

\section{David Shinn}

\begin{abstract}
This article identifies the respective interests of China and the United States in Africa - both Sub-Saharan and North Africa. By comparing the general strategies toward Africa and recent policy statements of the two countries, the article notes the important institutional differences in each country that impacts the implementation of policy in Africa and identifies the tools and tactics they use to achieve their respective goals. Subsequently, it evaluates the relative success that China and the United States have had in developing ties with African countries, indicating the countries with which China and the United States has each done especially well with respectively. Finally, the article identifies areas of China-U.S. cooperation and competition in Africa and suggests ways the two countries can further cooperate in a manner that will benefit Africa. It is concluded that China and the United States share very similar interests in Africa, and that their competition has been largely confined to economic arenas. Although the United States remains cautious of China's growing
\end{abstract}

David Shinn is Adjunct Professor in the Elliott School of International Affairs at George Washington University in Washington, D.C. He can be reached at dhshinn@earthlink.net.

(C) 2016 World Century Publishing Corporation and Shanghai Institutes for International Studies China Quarterly of International Strategic Studies, Vol. 2, No. 1, 35-55

DOI: $10.1142 / S 2377740016500020$ 
military presence in Africa, there is much room for their cooperation in promoting peace and development of the continent.

Keywords: China-Africa relations; the U.S.' Africa policy; U.S.-China competition; prospects for cooperation

\section{Introduction}

The mention of China and the United States in Africa often conjures up the image, especially in the journalistic community, of two heavyweights battling for political and economic control. While the two countries compete commercially, especially in trade and for big contracts, both countries compete similarly with all of the world's major trading nations. ChineseAmerican commercial competition in Africa is no different from ChineseIndian competition or American-French competition. It is also true that some analysts of China and the United States in Africa see the relationship as largely competitive. For example, Yun Sun at the Brookings Institution in Washington commented that "the fundamental cause of inadequate U.S.China cooperation in Africa is an underlying sense of zero-sum competition between the two powers on the continent." ${ }^{1}$

Once we leave the commercial arena, however, the situation is much more nuanced. While the governments of China and the United States employ different strategies and tactics in Africa, their interests are surprisingly similar. Leaders of both countries have emphasized that Africa is not a zerosum game in their foreign policy. During his visit to Africa early in 2008, former President George W. Bush commented that he did "not view Africa as zero-sum for China and the United States" and believed both countries "can pursue agendas without creating a great sense of competition." ${ }^{2}$ A few months later during a conference at Howard University in Washington on China-Africa relations, then Chinese Ambassador Zhou Wenzhong said that China appreciated President Bush's statement, adding that China and the

${ }^{1}$ Yun Sun, “The Limits of U.S.-China Cooperation in Africa," Africa in Focus, April 6, 2015, www.brookings.edu/blogs/africa-in-focus/posts/2015/04/06-limit-us-china-cooperation-inafrica-sun.

2“Bush Earmarks Aid for Tropical Diseases; He denies Rumors of Bases in Africa," The International Herald Tribune, February 21, 2008. 
United States need not pursue a "confrontational, or harmful rivalry, or a zero-sum game" ${ }^{3}$ in Africa.

Senior officials in both countries subsequently made this point in describing the broader U.S.-China relationship. Chinese Ambassador to the United States, Cui Tiankai, commented in 2014 that "there's so much interdependence and connectivity that relations between major countries are no longer a zero-sum game." ${ }^{4}$ President Obama's National Security Advisor, Susan Rice, also stated in 2015 that China-U.S. relations are not a zerosum game, for "our capacity to manage our differences is greater than that."

\section{Major Interests in Africa}

Critical to any country's foreign policy are its interests in another country or region. It is important, however, to be clear about definitions when we speak

Despite the general perception of

China-U.S.

competition in

Africa, their interests

in the continent are

surprisingly similar. of interests. This analysis refers to hard interests, i.e. what China and the United States want from Africa, not what they can do for Africa or would like to see occur in Africa. Both countries support, for example, economic development and poverty alleviation in Africa. While both countries strive to achieve these goals, they are not what China and the United States want from Africa and, therefore, they do not fit the definition of Chinese and American interests used here.

By that standard, China mainly has five interests in Africa, of which the relative importance to China may vary with time and situation:

- To ensure continuing access to oil, minerals, hardwood timber, and agricultural products.

${ }^{3}$ Quoted in David Shinn and Joshua Eisenman, "Responding to China in Africa," Policy Paper (Washington D.C.: American Foreign Policy Council, June 2008), p. 1, www.afpc.org/ publication_listings/viewPolicyPaper/236.

4 “China's Ambassador Says Ties with U.S. Are No Longer 'Zero-Sum Game,"” April 10, 2014, www.usip.org/publications/china-s-ambassador-says-ties-us-are-no-longer-zero-sum-game.

5 “U.S.-China Relationship Not a Zero-sum Game: Rice,” Xinhua News, September 21, 2015, http://news.xinhuanet.com/english/2015-09/22/c_134646293.htm. 
- To obtain political and economic support from as many as possible of Africa's 54 countries.

- To end Taiwan's diplomatic presence in Africa. (Three countries still recognize Taiwan as an independent state.)

- To increase Chinese exports to Africa.

- To minimize the impact of terrorism, international crime, narcotics trafficking, and piracy so they do not harm China's presence in Africa and the homeland.

The United States also has five major interests:

- To ensure continuing access to oil and a few specialized products.

- To obtain political and economic support from as many as possible of Africa's 54 countries.

- To increase U.S. exports to Africa.

- To minimize the impact of terrorism, international crime, narcotics trafficking, and piracy so they do not harm the U.S. presence in Africa and the homeland.

- To maintain access for U.S. military aircrafts to fly over and land in African territories and for U.S. Navy ships to call at African ports.

It can be seen that the interests of China and the United States in Africa are surprisingly similar. The two countries have four interests that are essentially the same. China has one unique interest, the universal acceptance of the "One China" policy and eventual diplomatic recognition by all African countries, while the United States has a military-security interest that China is yet to pursue to a similar extent. Although the need for the People's Liberation Army (PLA) Navy to access African ports is approaching, and China has acknowledged that it is discussing with the government of Djibouti concerning the establishment of some kind of military support facility there, its military presence as well as security ambition in Africa will remain far behind the United States in the foreseeable future.

\section{Long-Term Strategies Toward Africa}

China's top-down, Communist system of government has the advantage of being able to determine with some certainty its foreign policy one or even two decades into the future. There has been a relative continuity of strategy 
in China's Communist Party leadership since 1949, although there can be significant policy changes as happened after Deng Xiaoping took power. China's attention to the past and its own long history provide a backdrop for thinking long-term and strategically. This has been reflected in recent years in its strategy toward Africa.

China has attached a relatively high foreign policy priority to Africa as a world region. Arguably, it has been putting Africa ahead of Latin America and the Middle East, although both of these regions are gaining in importance vis-à-vis Africa. One reason for strong ties with Africa dates back to Africa's support for the Chinese mainland in 1971 to replace Taiwan in the United Nations. The large number of countries in Africa and the fact that they are major sources of key raw materials for China subsequently added to the continent's importance.

American democracy, on the other hand, does not lend itself to longterm strategic thinking. Political power changes every four or eight years in the executive branch and rarely do administrations develop foreign policies that can be assured of lasting beyond four years. Sometimes administrations have trouble thinking even beyond the next year. The American democratic system places considerable power in the hands of the Congress as foreign policy decisions require funding, making it more difficult to plan ahead with certainty. Advocacy and special interest groups can also have an enormous and unpredictable impact on foreign policy initiatives. Being a relatively young nation, the United States does not have a history of sweeping foreign policy strategic concepts. Isolationism, anti-communism or containment, and more recently support for democratization and an emphasis on counterterrorism tend to be mid-term strategies at most.

The U.S.' priority is

North Africa while

China tends to have a

long-term strategy

toward the whole

continent.

The United States attaches a great deal of importance to North Africa, especially Egypt. For operational purposes, however, the United States considers North Africa as part of the Middle East. Of all major world regions, Sub-Saharan Africa has always been at the bottom of U.S. foreign policy priorities. While there is a reasonable explanation for this situation, the fact that China accords Africa a somewhat higher priority gives it an 
advantage when comparing relative attention to the continent with the United States.

\section{Policies Toward Africa}

China published its first comprehensive policy document on Africa in $2006{ }^{6}$ It has subsequently updated this document with periodic high-level statements and by an action program every three years, developed during meetings of the Forum on China-Africa Cooperation (FOCAC). The last FOCAC Summit occurred in December 2015 in Johannesburg, South Africa. ${ }^{7}$ At this event, China issued its second Africa policy paper, which further clarified China's policy, taking into account new circumstances in the relationship. ${ }^{8}$

China's 2015 policy white paper makes the following key points:

- The "One China" principle remains a precondition for the establishment of relations with African countries.

- China will work more closely with the African Union and African subregional organizations.

- Both sides will intensify high-level exchanges, intergovernmental consultation and cooperation mechanisms, as well as exchanges between legislative bodies, political parties, the military, and local governments.

- Both sides will expand exchange and cooperation in cultural, economic, public security and other fields.

- China will prioritize support for Africa's industrialization and agricultural modernization. It will increase development assistance to Africa without political strings attached, following guidelines contained in the United Nations 2030 Agenda for Sustainable Development.

- China will help promote peace and security in Africa by deepening military cooperation and supporting Africa in combating non-traditional security threats such as piracy and terrorism.

6“China's Africa Policy," Xinhua News, January 12, 2006, http://news.xinhuanet.com/ english/2006-01/12/content_4042521.htm.

${ }^{7}$ The latest version is "The Forum on China-Africa Cooperation Johannesburg Action Plan (2016-2018)," December 10, 2015, http://www.chinese-embassy.org.za/eng/znjl/t1323229. htm.

8“China's Second Africa Policy Paper,” Xinhua News, December 4, 2015, http://news. xinhuanet.com/english/2015-12/04/c_134886545.htm. 
- China will support African countries in public health systems, education and human resource development, poverty alleviation, science and technology knowledge sharing, as well as climate change and environmental protection.

President Xi Jinping made a key speech at the 2015 FOCAC Summit in Johannesburg, South Africa, where he underscored the themes in the new policy paper and identified five pillars of the China-Africa relationship, ${ }^{9}$ whereby China will remain committed to: (1) political equality and mutual trust, which is the foundation of the China-Africa friendship; (2) promoting win-win economic cooperation; (3) mutually enriching cultural exchanges; (4) mutual assistance in security based on

While China seeks cooperation with Africa based on non-interference in each other's domestic affairs, the U.S. aims to improve democracy and human rights conditions and to encourage economic policy reform in African countries. development and eradication of poverty; and (5) solidarity and coordination in international affairs, especially in the context of the United Nations.

Since the end of World War II, the United States has periodically issued policy papers dealing with both Sub-Saharan and North Africa. Some of the themes have continued from one presidential administration to another while others are unique to a particular administration. The United States most recently outlined its policy toward Sub-Saharan Africa in a statement from the White House on 14 June 2012. ${ }^{10}$ The key points were:

- Strengthen democratic institutions in Africa by promoting accountable, transparent,

9 “President Xi Jinping Delivers Speech at FOCAC Summit," China Radio International, December 5, 2015, http://english.cri.cn/12394.2015.12/05/4083s906994.htm.

10 “U.S. Strategy toward Sub-Saharan Africa,” White House, June 2012, www. whitehouse.gov/sites/default/files/docs/africa_strategy_2.pdf. For U.S. policy on North Africa, see "Remarks by the President on the Middle East and North Africa," White House, May 19, 2011, www.whitehouse.gov/the-press-office/2011/05/19/remarks-president-middleeast-and-north-africa. 
and responsive governance and supporting leaders who create vibrant democratic models.

- Promote human rights, civil society, independent media, and strong democratic norms and ensure a sustained focus on the credibility of democratic processes while addressing humanitarian crises.

- Spur economic growth, trade, and development by supporting programs that enable an environment for trade and investment, and enhance lowemissions growth, as well as build resilience to climate change.

- Encourage development by addressing poverty, food security, public health, and opportunities for women and youth.

- Promote African regional integration and encourage more transparency and efficiency in the use of donor aid and management of public finances.

- Expand the African capacity to access and benefit from global markets and encourage U.S. companies to trade with and invest in Africa.

- Support United Nations and African peacebuilding and peacekeeping missions, and help counter terrorism in Africa and advance regional security cooperation and security sector reform.

- Prevent transnational criminal threats and conflict and mitigate mass atrocities and hold perpetrators accountable.

President Barack Obama repeated most of these themes in a speech on 28 July 2015 at the African Union in Addis Ababa, Ethiopia, but made the following additional points: ${ }^{11}$

- Only Africans can end corruption in their countries.

- Democracy must include free and fair elections, presidential term limits, freedom of speech and the press, and freedom of assembly.

- The American Young African Leaders Initiative is an effort to underscore the importance of African young people in the political process, while the Power Africa Initiative is aimed at reducing the number of Africans living without power.

- The United States will help African farmers improve their techniques and boost agricultural yields.

- The United States will work to create a new partnership between the African Union and United Nations to improve peace support operations.

11 “Remarks by President Obama to the People of Africa,” White House, July 28, 2015, www.whitehouse.gov/the-press-office/2015/07/28/remarks-president-obama-people-africa. 
- The United States stands with Africa in the fight against wildlife trafficking.

In sum, while the interests of China and the United States are very similar, their stated policies differ in several important ways. China says that it is primarily interested in cooperation with Africa, does not attach political strings to its aid, and prefers not to interfere in internal affairs, including in the case of human rights abuses and the democratization process. The United States, on the other hand, encourages Africans to democratize, improve human rights policies, and institute economic policy reform. In some cases, it ties its assistance to these principles.

\section{Institutions in Conducting African Affairs}

In the case of China, decision-making is concentrated at the top. The highest organ of executive power is the State Council, which includes the Premier, Vice Premiers and ministers, among others. The Ministry of Foreign Affairs advises Chinese leaders and helps implement African policy. It divides responsibility between a unit for Sub-Saharan Africa and one for West Asia and North Africa. China created FOCAC in 2000 to coordinate interaction with the 50 countries in North and Sub-Saharan Africa that recognize Beijing.

The Ministry of Commerce plays an important role on trade, aid, and investment. It has a Department of Foreign Aid. China's State-owned Assets Supervision and Administration Commission (SASAC) holds a rank equal to the Ministry of Foreign Affairs and the Ministry of Commerce. SASAC is either the sole owner of state-owned enterprises (SOEs) or maintains a controlling share of stock in SOEs, many of which do business in Africa. ${ }^{12}$ SASAC has branch offices in Africa. China's Export-Import Bank is the only state-owned entity that offers official economic assistance in the form of low interest loans, export credits, and guarantees. It has offices for Northern and Western Africa in Rabat, Morocco, and for Southern and Eastern Africa in Johannesburg, South Africa. ${ }^{13}$

${ }^{12}$ See SASAC website, http://en.sasac.gov.cn/n1408028/n1408521/index.html.

${ }^{13}$ See Export-Import Bank of China website, http://english.eximbank.gov.cn/tm/enTCN/index_617.html and http://english.eximbank.gov.cn/en/images/china_map.png. 
The International Department of the Communist Party of China (CPC) interacts with African counterparts to lay the foundation for commercial and diplomatic cooperation, exchange visits, and ensure that polices are implemented in accordance with CPC strategic objectives. China's Central Military Commission/PLA has frequent interaction with its African counterparts. China's official news service, Xinhua, has deep roots in Africa, regional bureaus in Cairo and Nairobi and more than 20 branch offices throughout Africa that report on developments in Africa and feeds information to African news services. Besides, China Central Television and China Radio International, which have programming offices in Nairobi, operate throughout Africa. All these services are under the control of the central government.

China's 22 provinces, five autonomous regions, four municipalities, and two special administrative regions (Hong Kong and Macau), which boast more than 100 twin relationships with African countries or cities, take directions from the CPC Central Committee while conducting independent interaction with African countries and cities at the same time. Their main interest is in promoting trade, obtaining commercial contracts (usually large infrastructure projects), encouraging investment in China, and providing modest aid to Africa. Chinese medical teams are sourced from a designated Chinese province and then twinned with an African country. Many SOEs operate directly from these Chinese sub-national jurisdictions.

China has 50 embassies in Africa, one in every country with which it has diplomatic relations. It also has nine independent consulates in Africa. Three African countries recognize Taiwan and Gambia has diplomatic relations with neither. Every African country that recognizes China also has an embassy in Beijing.

In comparison, U.S. institutions for dealing

The U.S.' economic engagement with Africa is driven by the private sector, but it has more active official institutions than China in many other arenas. with Africa feature both similarities and significant differences. The President takes advice from the National Security Council, relevant departments of government, and the Congress before making the most important policy decisions about Africa. The Africa Bureau of the State Department is responsible for Sub-Saharan Africa while North Africa is under the 
Bureau of Near Eastern Affairs. The State Department often shares responsibility with the Department of Defense on security matters, Department of Commerce and U.S. Trade Representative on trade issues, Treasury Department on international debt and financial issues, Federal Bureau of Investigation on legal matters, etc. The U.S. Agency for International Development (USAID) and Millennium Challenge Corporation are the principal assistance agencies while the Export-Import Bank and Overseas Private Investment Corporation play important roles in trade and investment.

The State Department and Voice of America (VOA) share public diplomacy efforts. While the State Department's public diplomacy reflects the position of the U.S. government, VOA presents the policies of the United States but allows discussion on a wide spectrum of views that may be critical of U.S. policy. ${ }^{14}$

The Director of National Intelligence, Central Intelligence Agency, National Security Agency, Defense Intelligence Agency, and State Department's Intelligence and Research Bureau provide intelligence support. The Africa Command (AFRICOM) located in Germany has the lead on militaryto-military relations. The United States has a large military base in Djibouti-Combined Joint Task Force-Horn of Africa (CJTF-HOA) - and small drone or fixed wing surveillance operations in Niger, Burkina Faso, and the Seychelles. ${ }^{15}$

American state governments have far more limited relationships with African countries than do Chinese provinces. States tend to confine their engagement to the exchange of trade missions and investment opportunities. On the other hand, well over 100 American cities have sister-city relationships with 160 African cities in 33 countries. ${ }^{16}$

The United States has 48 embassies in Africa, two fewer than China, and seven consulates or branch offices. Four of the 54 African countries that recognize the United States do not have embassies in Washington, DC, although two of them have missions accredited to the United States at the United Nations in New York.

${ }^{14}$ See www.insidevoa.com/info/voa-charter/2322.html.

${ }^{15}$ Eric Schmitt, “U.S. Signs New Lease to Keep Strategic Military Installation in the Horn of Africa," New York Times, May 5, 2014.

${ }^{16}$ See Sister Cities International Membership Directory, https://user-2221582232.cld.bz/ Sister-Cities-International-2015-Membership-Directory\#28. 
China and the United States have some structures in common, such as China's Ministry of Foreign Affairs and the U.S. State Department, respective Export-Import Banks, and embassy operations throughout most of Africa. Both the State Department and China's Ministry of Foreign Affairs divide responsibility for Africa internally between Sub-Saharan and North Africa, although FOCAC includes all the 50 African countries that recognize Beijing. Yet other institutions are very different. The CPC is far more active in Africa than the Republican and Democratic parties, which do not send high level, policy-mandated delegations to foreign countries as does the CPC. Delegations of U.S. senators and representatives usually visit on the basis of their congressional committee assignments and not as representatives of their political party. The National Democratic Institute and International Republican Institute operate in Africa as technical arms of their respective parties to improve voting procedures, encourage democracy, and monitor elections.

The United States has nothing comparable to China's State-owned Assets Supervision and Administration Commission. For the first time, the United States hosted most African leaders in Washington, DC in 2014, but there is no guarantee there will be another such summit and its purpose and structure were different than that of FOCAC. ${ }^{17}$ All U.S. companies operating in Africa come from the private sector unlike the important role played by China's large SOEs.

China Central Television and China Radio International are similar to Voice of America, but the latter permits more controversial discussion and criticism of U.S. policies and has more independence. The U.S. government has no organization similar to Xinhua. For its part, China has nothing like the Millennium Challenge Corporation, USAID, AFRICOM, CJTF-HOA, and a legislative branch that exerts considerable influence on policy in Africa.

\section{Tools and Tactics of Policy Implementation}

The United States and China use essentially the same political, economic, military, and cultural tools for implementing their policies in Africa.

${ }^{17}$ David Shinn, "Forum on China-Africa Cooperation vs US-Africa Summit," China-US Focus, September 10, 2014, www.chinausfocus.com/foreign-policy/forum-on-china-africacooperation-vs-us-africa-summit/. 
However, the emphases the two countries place on these tools, as well as the tactical way they implement policy varies considerably. China presents itself more humbly in its interaction with Africa, although this is changing rapidly as China's political and economic power increases. In contrast, having served as the leader of the Western world since the end of World War II and the only superpower since the end of the Cold War, the United States sometimes comes across in Africa as insensitive and arrogant.

China emphasizes high-level personal contact with African government leaders. President Hu Jintao made six trips to Africa, two as Vice President and four as President. President Xi Jinping included Africa on his first overseas visit after assuming the presidency. He then returned to attend the FOCAC summit in South Africa in 2015. Since 1993, Presidents Bill Clinton and George W. Bush each visited Sub-Saharan Africa twice and President Obama three times. China's Foreign Minister has made his first overseas visit every year since 1991 to Africa. By comparison, if visits to Cairo in connection with Middle East issues are excluded, there have been a number of years since 1991 that the American Secretary of State has not visited Africa.

China has also placed more emphasis on visits to Africa by senior officials from the CPC, PLA, and provincial governments. China has a particularly active program for inviting African leaders to China. The United States has done less well in receiving African leaders in Washington for bilateral visits, but does take advantage of their presence at the annual fall United Nations' session in New York as well as World Bank and International Monetary Fund meetings in Washington to arrange high-level meetings.

The United States has a natural advantage in building relations with the civil society, non-governmental organizations, think tanks, independent labor unions, opposition political parties, and university communities. The United States attaches more importance to these organizations or, in the case of universities and think tanks, has more of them. China has minimal contact with most of these groups because it has had very little experience in dealing with similar groups in China. Both China and the United States interact effectively with the African business community, although the 
Chinese government and business sector in recent years have worked harder toward this goal than the U.S. government and private sector.

Nearly all of the assistance provided to Africa by the United States is in the form of grants. The amounts increased significantly during the George W. Bush administration and these high levels continue in the Obama administration, with continued focus in the areas of humanitarian aid, combating HIV/AIDS, TB and malaria, and human capacity building. In recent years, U.S. aid to Africa has been running at about $\$ 8$ billion annually.

China offers a modest amount of grant

The U.S. and China employ basically the same policy tools in their engagement with Africa, yet with different emphases and tactics. aid, but is much better known for its huge, low-interest, long-term loans, which are often repaid by shipping Africa's oil and minerals to China. Recipient countries use most of the loans for major infrastructure projects built by Chinese companies, which use a significant amount of Chinese material, and usually a percentage of Chinese labor. The concessionary components of the loans constitute most of China's aid to Africa, which is estimated from 2010 to 2012 at about $\$ 2.5$ billion annually. ${ }^{18}$

China is setting up seven special economic zones in Africa that offer Chinese companies favorable incentives, tax breaks, and reliable electric power. They have been established or are under construction in Zambia (two), Nigeria (two), Egypt, Ethiopia, and Mauritius, though it is still too early to judge their success. ${ }^{19}$ The United States, in contrast, has no comparable program.

Chinese medical teams to Africa date back to 1963 in Algeria and have been well-received. Thousands of medical personnel have participated over

${ }^{18}$ Chinese State Council, “China's Foreign Aid,” July 2014, http://english.peopledaily. com.cn/n/2014/0710/c90883-8753777.html.

${ }^{19}$ Douglas Zhihua Zeng, “Global Experiences with Special Economic Zones-With a Focus on China and Africa" (Washington D.C.: World Bank, February 2015), pp. 13-14, www.worldbank.org/content/dam/Worldbank/Event/Africa/Investing\%20in\%20Africa \% 20Forum/2015/investing-in-africa-forum-global-experiences-with-special-economic-zoneswith-a-focus-on-china-and-africa.pdf. 
the years. Chinese medical teams are now located at more than 200 medical stations in 42 African countries. ${ }^{20}$ For its part, since 1961, the highly successful U.S. Peace Corps has sent more than 100,000 volunteers to nearly every country in Africa. Today, more than 3,000 Peace Corps volunteers serve in 29 African countries. ${ }^{21}$ In 2007, China began sending its first young volunteers to Africa; they number about 300 per year. China has 45 Confucius Institutes in African universities and ten Confucius Classrooms in secondary schools in 35 African countries. ${ }^{22}$ The United States has no similar program.

China became active in UN peacekeeping operations in Africa beginning in 2000. Today, it has more than 2,600 military people, police officers and experts assigned to seven of the nine UN peacekeeping operations in Africa. The largest contingents are in Liberia, the Democratic Republic of the Congo, South Sudan, Sudan, and Mali. ${ }^{23}$ By comparison, the United States has about 40 Americans assigned to UN peacekeeping operations in Africa. On the other hand, the United States funds about 28 percent of the UN peacekeeping budget while China funds about 6 percent.

The United States has a robust military presence in Africa. The Combined Joint Task Force-Horn of Africa base in Djibouti has about 4,000 personnel who are working primarily on counterterrorism. U.S. naval vessels frequently visit African ports and military aircrafts often fly over or land in African airports. From the beginning, the United States has been active in the anti-piracy effort off Somalia. Since the end of 2008, China has sent two destroyers and a supply ship to the Gulf of Aden to assist with this effort, which resulted in a significant increase in PLA Navy visits to African ports. Since 2010, there have been more than 30 PLA Navy port calls in about a dozen African countries. ${ }^{24}$ China has no military bases in Africa but

${ }^{20}$ Jiao Feng, “Chinese Doctors in Africa,” China Today, June 29, 2015, www.chinatoday. com.cn/english/report/2015-06/29/content_693869.htm.

${ }^{21}$ See Peace Corps website, www.peacecorps.gov/about/fastfacts/.

${ }^{22}$ See Hanban website, http://english.hanban.org/node_10971.htm.

${ }^{23}$ See UN website, www.un.org/en/peacekeeping/contributors/2015/oct15_3.pdf.

${ }^{24}$ Andrew S. Erickson and Austin M. Strange, “China's Blue Soft Power: Antipiracy, Engagement, and Image Enhancement," Naval War College Review, Vol. 68, No. 1 (Winter 2015), pp. 81-82. 
is in discussion with the government of Djibouti concerning some kind of facility to support its more frequent naval visits to the region. ${ }^{25}$

China has a strong presence of ethnic Chinese in Africa, which is estimated to number more than one million. Some of those living in South Africa, Madagascar, Seychelles, and Mauritius date back more than a century. More recent arrivals of Chinese small traders and entrepreneurs are creating new communities in Africa. The United States has nothing comparable, although Liberia has always had a close connection because some of its population originated from former slaves in the United States. Increasing numbers of Africans from the diaspora in the United States are also returning to Africa for lengthy visits or even to live permanently.

\section{African Response to the U.S. and China}

A number of African governments are autocratic and some organized on a political model similar to that in China. China has a natural advantage in building relationships with African governments because it eschews the lecturing on governance and human rights often employed by the United States. Nevertheless, the fact that the United States remains the world's leading power gives it a certain cachet with African governments even if it comes with a degree of resentment. Like it or not, African governments find it difficult to ignore the United States, yet a few African leaders tend to believe that China will replace the United States in the not distant future as the world's leading power.

China has established cordial, and in some cases warm, relationships with all the 50 African governments that recognize Beijing. Although the United States has diplomatic relations with 54 African countries, there are wider differences in the quality of the bilateral relationships. This is probably due to a combination of Washington's policy of political conditionality and the fact that the United States has been more engaged over the years in controversial African issues such as the toppling of the Muammar alQaddafi regime in Libya and the imposition of sanctions on Sudan.

Looking at the continent region by region, China struggled in North Africa in the aftermath of the Arab spring as its policy seemed to prevent it

${ }^{25}$ Jane Perlez, "China to Build Up Military Presence in Djibouti," New York Times, November 6, 2015. 
from reacting quickly and effectively to dramatic change. Relations with Algeria, Morocco, and Tunisia are back on track and ties with Egypt may be stronger than during the Hosni Mubarak government. Libya remains a challenge. The United States, which has also struggled with its policy in North Africa, has been more engaged politically than China. This has caused serious strains in its relations with Egypt and a sense of confusion in Libya. It has solid ties with Morocco and Tunisia and satisfactory relations with Algeria.

Both the United States and China have cordial relations with the Sahel countries except that Burkina Faso recognizes Taiwan. China's economic ties are stronger throughout the region, including trade with Burkina Faso, and China is an important contributor of troops to the UN peacekeeping operation in Mali. The United States has significant security ties across the region, especially a drone surveillance operation in Niger and fixed wing surveillance contract arrangement in Burkina Faso.

The United States has developed good relations with key countries in West Africa, such as Nigeria, Ghana, Senegal, Côte d'Ivoire, and Liberia, and even has more trade with Nigeria than China, which has an equally good relationship with these countries. Except for Gambia, which recognizes neither Beijing nor Taipei, China generally has a warmer relationship with most of the other governments in the region.

While China generally does better with African governments, the U.S. enjoys more favorable response from African civil society.

China's economic ties with most of the countries in Central Africa are more significant than those of the United States. Its relationship with the governments of these countries is also generally warmer because China does not hector the leaders over their poor human rights practices and reluctance to democratize. Sâo Tomé and Principe recognizes Taiwan but has more trade with the Chinese mainland than it has with either Taiwan or the United States. The most important country in the group, the Democratic Republic of the Congo, has good relations with both the United States and China but is a major trade partner with China and recipient of Chinese loans.

The six countries in the Horn of Africa are challenges for both China and the United States due to their internal conflicts and problems with neighbors. The United States has a poor relationship with Sudan and 
Eritrea and recently strained ties with South Sudan. It has cordial links with Ethiopia, Djibouti, and Somalia. China has strong economic ties with most of the countries in the region and a cordial political relationship with all of them. At the same time, it is struggling in its efforts to preserve its oil interests in South Sudan, where it is also a major contributor of troops to the UN peacekeeping operation.

The United States and China do about equally well with the governments of the three East African countries, although China may have an edge with the current Kenyan government. China has generally done better than the United States with the four Indian Ocean Island governments; the United States does not even have an embassy in the Seychelles and Comoro Islands.

China's economic and political relations with the governments of Southern African countries are uniformly strong except for Swaziland, which recognizes Taiwan. Angola and South Africa are its major trading partners in Africa. A high percentage of China's foreign direct investment has gone to Southern Africa. The CPC has developed especially strong ties with the ruling parties of South Africa, Zimbabwe, Angola, Namibia, and Mozambique. The United States has cordial relations with most of the governments in the region except for a difficult relationship with the Robert Mugabe government in Zimbabwe and increasingly strained ties with the African National Congress (ANC)-led government in South Africa.

While China generally does better with African governments than does the United States, there are elements of the African society that respond more favorably to the United States. These groups include civil society organizations, opposition political parties, independent labor unions, and the non-government media sector. University and business communities seem to be about equally satisfied with both countries. The Pew Research Center did a global survey in 2015 that looked at favorable/ unfavorable views of the United States and China. The survey included nine countries in Sub-Saharan Africa. Both China and the United States received their most favorable rankings in Sub-Saharan Africa as compared to other world regions. The favorable rating for the United States was 79 percent and for China 70 percent. $^{26}$

${ }^{26}$ Richard Wike, “5 Charts on America's (Very Positive) Image in Africa," Pew Research Center, July 23, 2015, www.pewresearch.org/fact-tank/2015/07/23/5-charts-on-americasvery-positive-image-in-africa/. 


\section{U.S.-China Competition and Cooperation}

Much of the public discussion on China in Africa has focused on the degree to which China is competing with or even trying to replace the influence of the United States and Western countries in Africa. There is, of course, commercial competition and there are some issues in Africa where the United States and China disagree, which may give the impression of greater competition than the situation justifies. For example, there were disagreements in 2005-2006 over the best approach to end conflict in Sudan's Darfur region. China supported the position of Sudanese President Omar al-Bashir while the United States placed sanctions on Sudan. China and the United States also disagreed in 2011 over policy toward Libya and the future of the Muammar al-Qaddafi regime.

The United States uses its leverage in Africa to encourage improvements in human rights practices and the pursuance of Western style liberal democracy. China, on the other hand, has a policy of no political strings attached to its aid and maintains good relations with African governments whether they are democracies, autocracies, military regimes, or Islamist. This is arguably the biggest difference in Chinese and American policy toward Africa.

Although the U.S. is cautious of China's growing military presence in Africa, both countries share great prospects for cooperation in promoting peace and development of the continent.

China is stepping up its bilateral security relationships with Africa as it expands the size and role of the PLA Navy. This has led to a significant increase in port calls in Africa. Should the outcome of China's negotiations with Djibouti or other African countries result in a formal military base, it may raise eyebrows in Washington even though the United States has a large base in Djibouti and drone surveillance operations elsewhere. The nature of Washington's reaction will probably be determined by the purpose and size of any Chinese military facility in Africa.

More importantly, there are numerous areas in which China and the United States are cooperating or have the potential to cooperate. In Africa, both countries generally seek political 
stability, economic development, and the minimization of negative developments such as terrorism, piracy, narcotics trafficking, and international crime. Both support UN and African Union peacekeeping efforts and international efforts to combat piracy.

The two countries have collaborated in efforts to encourage stability and reduce conflict in Sudan, South Sudan, and Somalia. China was instrumental in convincing President Bashir of Sudan to accept a hybrid African Union/United Nations peacekeeping force in Darfur, where Chinese peacekeepers subsequently were assigned. ${ }^{27}$ Both countries have backed policies at the United Nations that support the Somali Federal government. They have also provided financial assistance to the African Union peacekeeping mission in Somalia aimed at combating extremism. ${ }^{28}$ China and the United States are part of the same group, which includes the United Kingdom and Norway that supports the Intergovernmental Authority for Development mechanisms for achieving peace in South Sudan. ${ }^{29}$

There is great potential for cooperation in economic development as well. The United States and China have unique strengths, for example, in working together to help improve African agriculture and health care. Countering malaria is a scourge where both the United States and China can add value to prevention programs. Both countries have successful agricultural sectors, components of which could be combined and adapted to improve production in Africa.

The prevention of natural disasters and provision of emergency relief are other areas where the two countries can cooperate to the advantage of African countries. The time has come to focus more on areas of current or potential collaboration and to pay less attention to the debilitating debate about U.S-China competition. But U.S.-China cooperation is most likely to

${ }^{27}$ David Shinn, "China and the Conflict in Darfur," The Brown Journal of World Affairs, Vol. 16, No. 1 (Fall/Winter 2009), pp. 91-94.

${ }^{28}$ The White House, “Fact Sheet: U.S. Support for Peacekeeping in Africa," August 6, 2014, www.whitehouse.gov/the-press-office/2014/08/06/fact-sheet-us-support-peacekeeping-africa; African Union, “The People's Republic of China Extends Financial Support to the African Union Mission in Somalia," Press Release, December 10, 2015, www.peaceau.org/uploads/auccom-chinese-contribution-10-12-2015.pdf.

${ }^{29}$ Liesl Louw-Vaudran, “China's Role in South Sudan a Learning Curve," Institute for Security Studies, December 14, 2015, www.issafrica.org/iss-today/chinas-role-in-southsudan-a-learning-curve. 
happen if African leaders take the initiative and encourage both countries (and perhaps others) to collaborate on specific projects.

In conclusion, there are definitely issues in Africa where China and the United States compete as major powers of the world, but there are many more fields where they can - and should - cooperate. Africa is neutral territory for both the United States and China. It is the one major region of the world that best lends itself to cooperation. While there are more significant disagreements between the United States and China unrelated to Africa, it should be possible to sideline these differences when it comes to Africa. It is in large part up to African leaders, however, to make such cooperation possible. 